\section{Commentary: Innovation...or disruption and the delayed acknowledgement of a new reality}

\author{
Jacob A. Klapper, MD
}

In the 20th century, technologic advancements were known as innovation, and the patrician men who shepherded them wore 3-piece suits and somber expressions. Nowadays, innovation is no longer in vogue and it has been summarily replaced for the somewhat-unsettling term "disruption," this time promoted largely by men (still, sadly) clothed in more proletariat-style dress and with suspiciously warmer smiles. Disruption now occurs so quickly that for a time, not just the Luddites but those less opposed to change remain somewhat beholden to the established way of doing things. We see this in the persistence of print media, taxi companies, attempts at compassionate civil discourse, and medicine.

The manuscript by Lehr and colleagues ${ }^{1}$ questions the wisdom of persisting with the designation of increasedrisk donors (IRDs) despite innovations (disruptions in the current parlance) in diagnosis and treatment. The term "increased risk" was designed to denote those donors who, while not actively infected with either HIV, hepatitis $\mathrm{B}$ virus, or hepatitis $\mathrm{C}$ virus (HCV), were considered to be in that unique "window" period where their risk of transmission is particularly high. As this paper compelling demonstrates, such a term may unnecessarily stigmatize a large subset of the US donor population, with the adverse downstream effect of biasing potential recipients against accepting these organs.

The evidence would bear this out, as a large percentage of would-be recipients turn down these otherwise-acceptable organs $(>70 \%)$ despite the reality that nucleic acid testing makes the likelihood of contracting one of these

\footnotetext{
From the Division of Cardiothoracic Surgery, Duke University Medical Center, Durham, NC.

Disclosures: Author has nothing to disclose with regard to commercial support.

Received for publication Oct 25, 2019; revisions received Oct 25, 2019; accepted for publication Oct 26, 2019; available ahead of print Nov 20, 2019.

Address for reprints: Jacob A. Klapper, MD, Division of Cardiothoracic Surgery,

DUMC 3954, Durham, NC 27710 (E-mail: Jacob.klapper@ duke.edu).

J Thorac Cardiovasc Surg 2020;160:583-4

$0022-5223 / \$ 0.00$

Published by Elsevier Inc. on behalf of The American Association for Thoracic Surgery

https://doi.org/10.1016/j.jtcvs.2019.10.170
}

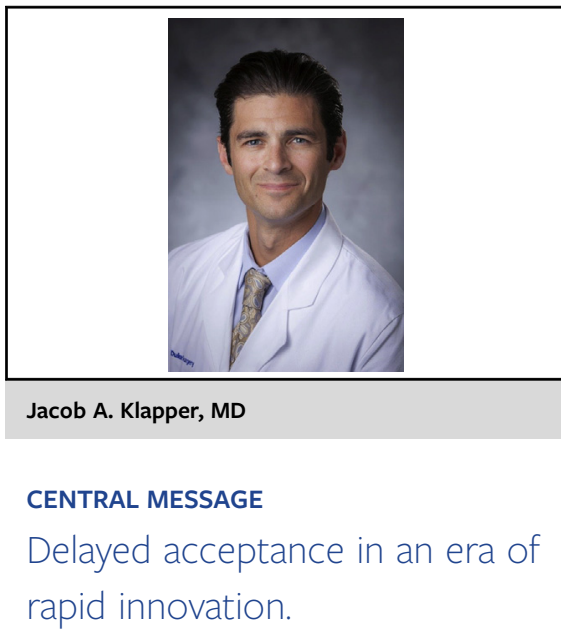

communicable viruses unlikely. Admittedly, a chance still does exist, so why not just wait for something less risky? Recent evidence would suggest that executing such caution is itself not without risk and may likely be detrimental to survival. Cox and colleagues ${ }^{2}$ recently published data demonstrating that, of patients who turned down and initial IRD offer, nearly $14 \%$ died or decompensated and another $15 \%$ were still awaiting transplant a year later. In addition, the patients who accepted the initial IRD had a significantly improved mortality at 1 and 5 years as compared with those who declined. ${ }^{2}$

Aside from the assurances that nucleic acid testing provides, the effective treatments for HCV further diminish concerns over the transmission of this virus. Again, recent evidence has demonstrated that the transplantation of HCV-infected donors can be done safely, with persistent eradication of the viral load, and well-maintained graft function. Perhaps most remarkably, achievement of undetectable viral loads can be seen after 4 weeks of treatment, thus eliminating the necessity for additional chronic medication use and the potential for complicated long-term drug interactions. ${ }^{3}$

In an era in which we, in the world of transplant, bear particular witness to what the opioid epidemic has wrought across America, medical science now allows for us to make use of these lost lives, now more safely than ever before. Donors with these tragic narratives are the new reality, and it is time to fully realize, across the community, the unforeseen opportunities for others that these innovations have created.

\section{References}

1. Lehr CJ, Lopez R, Arrigain S, Schold J, Koval C, Valapour M. The impact of change in definition of increased-risk donors on survival after lung transplant. J Thorac Cardiovasc Surg. 2020;160:572-81. 
2. Cox M, Mulvihill M, Choi A, Bishawi M, Osho AA, Haney JC, et al. Implications of declining donor offers with increased risk of disease transmission on waiting list survival in lung transplantation. J Heart Lung Transplant. 2019;38:295-305.
3. Woolley A, Singh S, Goldberg H, Mallidi HR, Givertz MM, Mehra MR, et al. Heart and lung transplants from HCV-infected donors to uninfected recipients. N Engl J Med. 2019;380:1606-17. 